
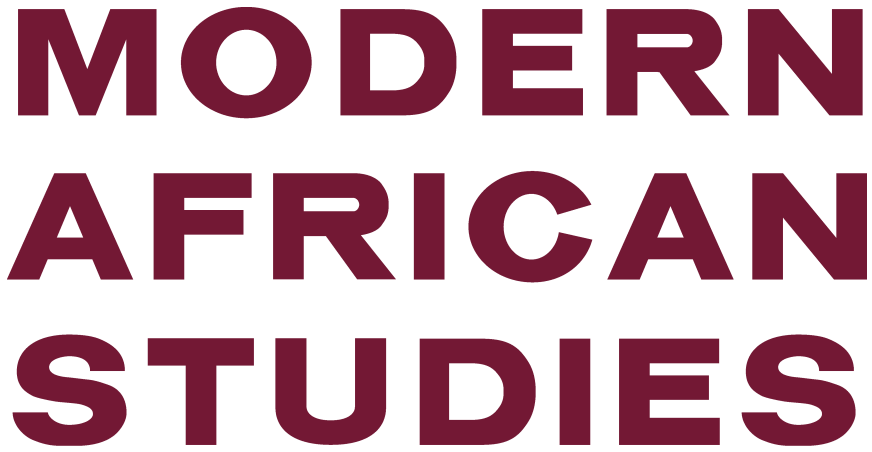

VOLUME 55 NUMBER 2 JUNE 2017

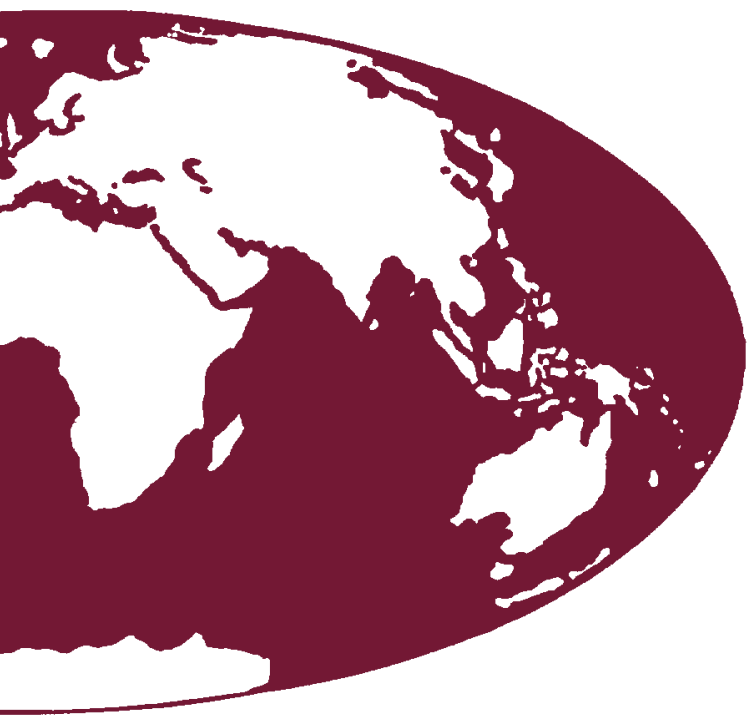

NOEL STRINGHAM AND

JONATHAN FORNEY

It takes a village to raise a militia: local politics, the Nuer White Army, and South Sudan's civil wars

\title{
VUSILIZWE THEBE
}

Legacies of 'madiro'? Worker-peasantry,

livelihood crisis and 'siziphile' land occupations in semi-arid north-western Zimbabwe

TERJE $\varnothing S T E B \varnothing$ AND

WALLELIGN SHEMSEDIN

Ethiopian Muslims and the discourse about moderation

ELIZABETH HARRISON AND ANNA MDEE Size isn't everything: narratives of scale and viability in a Tanzanian irrigation scheme

MATTHEW BRUBACHER,

ERIN KIMBALL DAMMAN AND

CHRISTOPHER DAY

The AU Task Forces: an African response to transnational armed groups

FRANCESCO CAVATORTA AND

RAQUEL OJEDA GARCIA

Islamism in Mauritania and the narrative

of political moderation

A QUARTERLY SURVEY OF POLITICS, ECONOMICS

\& RELATED TOPICS IN CONTEMPORARYAFRICA

EDITED BY PAUL NUGENT AND LEONARDO A. VILLALÓN 


\section{THE JOURNAL OF MODERN AFRIGAN STUDIES}

\section{EDITORS}

Paul Nugent, Centre of African Studies, Chrystal Macmillan Building, 15A George Square, Edinburgh EH8 9CD, UK

Leonardo A. Villalón, Center for African Studies \& Dept of Political Science, The University of Florida, PO Box 115560, Gainesville, FL 32611-5560, USA; email: jmas@cambridge.org

Book Review Editor: Elliott Green, Department of International Development, London School of Economics, Houghton Street, London WC2A 2AE, UK; e-mail: E.D.Green@lse.ac.uk

Associate Editor: Maggie Dwyer, Centre of African Studies, Chrystal Macmillan Building, 15A George Square, Edinburgh EH89CD, UK; email: jmas@cambridge.org

\section{EDITORIAL ADVISORY BOARD}

Kojo Amanor, University of Ghana

Joseph Ayee, MountCrest University College, Ghana

Catherine Boone, London School of Economics

Mighael Bratton, Michigan State University

Brenda Chalfin, University of Florida

Rosaleen Duffy, University of Sheffield

Pierre Englebert, Pomona College

Harri Englund, University of Cambridge

James Ferguson, Stanford University

Vincent Fougher, Université de Bordeaux

Jefrrey Herbst, Colgate University

Peter Lewis, SAIS, fohns Hopkins University, Washington DC

Terrenge Lyons, George Mason University

Kenneth Menkhaus, Davidson College

Lungisile Ntsebeza, University of Cape Town

Francis Nyamnjoh, University of Cape Town

Ebenezer Obadare, University of Kansas

Will Reno, Northwestern University

KJetil Tronvoll, University of Oslo

Denis M. Tull, German Institute for International Affairs and Security, Berlin

Nigolas van de Walle, Cornell University

Jankees van Donge, Afrikastudiecentrum Leiden

\section{SUBSCRIPTIONS}

The Fournal of Modern African Studies (ISSN: 0022-278x) is published quarterly by Cambridge University Press, Journals Fulfillment Department, UPH, Shaftesbury Road, Cambridge CB2 8BS, UK. Journals Fulfillment Department, Cambridge University Press, I Liberty Plaza, Floor 20, New York, NY 10006, USA and 477 Williamstown Road, Port Melbourne, vIC 3207, Australia.

The subscription price (which includes postage by air where appropriate, plus electronic access to institutional subscribers) of volume 55, 2017, is $£ 360$ net (US \$6r8 in the USA, Canada and Mexico) for institutions, $\mathcal{E}_{3}$ (US \$102) for individuals ordering direct from the publishers and certifying that the foumal is

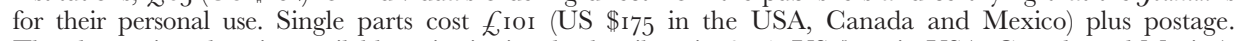
The electronic only price available to institutional subscribers is $£_{3} 08$ (US \$523 in USA, Canada and Mexico). Four parts form a volume. EU subscribers (outside the UK) who are not registered for VAT should add VAT at their country's rate. VAT registered subscribers should provide their VAT registration number.

Orders, which must be accompanied by payment, may be placed with a bookseller or subscription agent or sent to the publishers (in the USA, Canada and Mexico to the American Branch). Japanese prices for institutions are available from Kinokuniya Company Ltd, P.O. Box 55, Chitose, Tokyo 156, Japan.

Copies of the Fournal for subscribers in the USA, Canada and Mexico are sent by air to New York to arrive with minimum delay. Periodicals postage paid at New York, NY, and at additional mailing offices. Postmaster: send address changes in USA, Canada and Mexico to The Fournal of Modern African Studies, Cambridge University Press, I Liberty Plaza, Floor 20, New York, NY 10006, USA.

Claims for missing issues will only be considered if made immediately on receipt of the subsequent issue.

\section{Internet Access}

This journal is included in the Cambridge Journals Online service which can be found at cambridge.org/moa. For further information on other Press titles access cambridge.org

\section{Copying}

This journal is registered with the Copyright Clearance Center, 222 Rosewood Drive, Danvers, MA or923. Organisations in the USA who are also registered with C.C.C. may therefore copy material (beyond the limits permitted by sections 107 and 108 of US copyright law) subject to payment to C.C.C. of the per copy fee of \$12.00. Code 0022-278x/2017/\$12.00. This consent does not extend to multiple copying for promotional or commercial purposes. ISI Tear Sheet Service, 350r Market Street, Philadelphia, Pennsylvania 19I04, USA, is authorised to supply single copies of separate articles for private use only. Organisations authorised by the Copyright Licensing Agency may also copy material subject to the usual conditions. For all other use, permission should be sought from Cambridge or the American Branch of Cambridge University Press. 


\section{THE JOURNAL OF MODERN AFRICAN STUDIES}

\begin{tabular}{llll} 
VOLUME 55 & JUNE 2017 & NUMBER 2 \\
\hline
\end{tabular}

\section{ARTICLES}

IT TAKES A VILLAGE TO RAISE A MILITIA: LOCAL POLITICS, THE NUER WHITE ARMY, AND SOUTH SUDAN'S CIVIL WARS

NoEl Stringham and Jonathan Forney

LEGACIES OF 'MADIRO'? WORKER-PEASANTRY, LIVELIHOOD CRISIS AND 'SIZIPHILE' LAND OCCUPATIONS IN SEMI-ARID NORTH-WESTERN ZIMBABWE

Vusilizwe TheBe

201

ETHIOPIAN MUSLIMS AND THE DISCOURSE ABOUT MODERATION

Terje $\varnothing$ steb $\varnothing$ and Wallelign Shemsedin

SIZE ISN'T EVERYTHING: NARRATIVES OF SCALE AND VIABILITY IN A TANZANIAN IRRIGATION SCHEME

Elizabeth HARRISON and ANNA MDEE

THE AU TASK FORGES: AN AFRICAN RESPONSE TO

TRANSNATIONAL ARMED GROUPS

Matthew Brubacher, Erin Kimball Damman and CHRISTOPHER DAY

ISLAMISM IN MAURITANIA AND THE NARRATIVE OF POLITICAL MODERATION

Francesco Cavatorta and Raquel Ojeda Garcia

\section{REVIEWS}

Women and Power in Postconflict Africa by A IL I M A R I T R I P P Meredeth Turshen, Rutgers University

The Financialisation of Power: How Financiers Rule Africa by S A R A H B R A C K I N G Keith Hart, London School of Economics and Political Science

The Green State in Africa by C A R L D E A T H

M. A. Mohamed Salih, International Institute of Social Studies, Erasmus University Rotterdam

Made in Africa-Learning to Compete in Industry by CA R L L NeWman, John Page, John Rand, Abebe Shimeles, Måns Söderbom and Finn Tarp Jostein Hauge, University of Cambridge 
The Paradox of Traditional Chiefs in Democratic Africa by K A T E B A L D w I N

Dominika Koter, Colgate University

Africa and the Millennium Development Goals: Progress, Problems and Prospects edited by

Charles Mutasa and Mark Paterson

Nathan Andrews, Queen's University, Canada

Assembling Export Markets: The Making and Unmaking of Global Food Connections in West Africa by STEFAN OUMA

Allison Loconto, Interdisciplinary Laboratory for Science, Innovation and Society (LISIS) French National Institute for Agricultural Research (INRA)

Guinea-Bissau: Micro-State to Narco-State edited by P A т г г к С н в а L and T о в Y GREE N

Vincent Foucher, International Crisis Group

Histoire de l'Agence française de développement en Côte d'Ivoire by F R A N C O IS

PACQUEMENT

Gordon D. Cumming, Cardiff University

The Petro-Developmental State in Africa: Making Oil Work in Angola, Nigeria and the Gulf of Guinea by Jesse Salah Ovadia

Omolade Adunbi, University of Michigan

Moral Economies of Corruption: State Formation and Political Culture in Nigeria by S T E v E N PIERCE

Omobolaji Ololade Olarinmoye, Hamilton College

The Responsibility to Protect and the International Criminal Court: Protection and Prosecution in Kenya by Serena Sharma

Thomas Obel Hansen, Transitional Justice Institute, Ulster University

From Classrooms to Conflict in Rwanda by E L IS A B E T H KING

Tejendra Pherali, UCL Institute of Education 